International Journal of Agriculture, Environment and Bioresearch

Vol. 06, No. 04; 2021

ISSN: $2456-8643$

\title{
BUFFER CROPS AS MITIGATION MEASURE AGAINST CROP DAMAGE BY WILDLIFE: A CASE OF FARMERS BORDERING KIBALE NATIONAL PARK, WESTERN UGANDA
}

\author{
Rusoke Taddeo $^{1,2}\left(\right.$ R.T), Orach-Meza Faustino ${ }^{1}$ (O.F) \\ ${ }^{1}$ Nkumba University, School of Sciences, Entebbe 237, Uganda \\ ${ }^{2}$ Africa One Consult Limited, Entebbe Uganda \\ https://doi.org/10.35410/IJAEB.2021.5652
}

\begin{abstract}
The paper is a review of literature related to mitigation of crop damage by wildlife with a view to identifying information gaps and proposing suitable mechanisms for mitigating crop damage by wildlife among farmers bordering Kibale National Park. Basing on the Optimal Foraging Theory (OFT), The paper focused on practices of crop damage by wildlife and their mitigation. The concept of cultivating buffer crops as a mitigation measure against crop damage by wildlife is elaborated. The effect of wildlife damage on crops in absence of buffer crops, and the effect of farmers participation in mitigation of crop damage by wildlife through cultivation of buffer crops is discussed. A conceptual derivative from the review which contributes to improving farmers livelihoods through mitigation of crop damage by wildlife has also been developed as the outcome of the review.
\end{abstract}

Keywords: Buffer Crops, Mitigation of Crop Damage by Wildlife, Kibale National Park, Uganda.

\section{INTRODUCTION}

Wild animals continue to cause damage to crops grown by farmers bordering protected areas (McLennan and Hill, 2012; Krithi et al., 2012), but cultivation of buffer crops has proved relatively effective in mitigation of crop damage by wildlife. Cultivation of buffer crops consist of planting less or non-palatable crops to wildlife, crops which create a low conflict barrier; crops which enrich the forest edge and entice crop damaging wildlife species to remain in the forest (Akampulira et al., 2015). Such crops are beneficial to farmers both commercially and on subsistence basis (Senthilkumar et al., 2016). Absence of buffer crops results in crop damage by wildlife, and individual farmers living close to protected area boundaries continue to suffer agricultural losses as a result of crop damage by wildlife (Nath et al., 2015).

Tania et al, (2001) proposed the development of non-agricultural activities on land directly adjacent to the forest, though this idea is best suited for urban environment, around Kibale National Park(KNP) where farmers bordering the protected areas are predominantly involved in crop cultivation, the development of non-agricultural activities might not be feasible (L'Roe and Naughton-Treves, 2017). Hence a review of buffer crops as mitigation measure to crop damage 
by wildlife could contribute to mitigation of crop damage by wildlife through cultivation of buffer crops as a modification to farming practices around KNP.

Modification of farming practices (Akankwasah, 2008) such as planting of crops which are less palatable or appealing to wildlife, or planting of crops that are commonly damaged by wildlife beyond a buffer of unappealing crops or habitat, may present a more effective and sustainable solution to crop damage by wildlife (Hockings and Hulme, 2009). Study findings by Akankwasah 2008 support this proposed study on the use of buffer crops as mitigation to crop damage by wildlife. Other crop damage by wildlife management techniques such as maintenance of fences and/or reliance on guarding crop gardens by dogs (Hill, 2012) could complement the cultivation of buffer crops.

This review was guided by the Optimal Foraging Theory (OFT), as a behavioral ecology model that helps to predict how wild animals behave when searching for food. Crop damage by wildlife is facilitated by cultivation of food crops which are richer in nutrient value compared to plants found within protected areas, therefore, mitigating crop damage by wildlife requires participation of farmers in cultivation of buffer crops that are not fed on by wildlife. Nishant et. al. (2019) demonstrates that cultivated plants are richer in macronutrients and mineral salts than wild plants of the same taxa. This implies that as long as farmers continue to grow food crops at the border of the Park, crop damage by wildlife is inevitable. This review presents literature on types of buffer crops grown by farmers to mitigate crop damage by wildlife, the effect of crop damage by wildlife on crops grown in absence of buffer crops, and the effect of crop farmers involvement in planting of buffer crops as a mitigation measure to crop damage by wildlife around Kibale National Park. As an outcome of the review a conceptual model on buffer crop cultivation as mitigation measure against crop damage by wildlife has been developed.

\section{METHODS}

The information provided in the review paper was obtained from existing literature on buffer crops grown, wildlife crop damage mitigation and farmers participation in cultivation of buffer crops across other national parks in Uganda and Africa. The review based on Optimal Foraging Theory (OFT) to explain the cause of crop damage by wildlife and how farmers can mitigate losses incurring from the damages by wildlife.

\section{FINDINGS}

\section{Types of buffer crops grown to mitigate crop damage by wildlife}

Where protected areas end, crops and gardens begin (Sieler and Robbins, 2015). The study conducted by (Sieler and Robbins, 2015) found tea to be an effective deterrent/buffer crop against gorillas. This study elucidates that gorillas dislike crossing through the tea plantations and do not feed on the crop. Planting buffer crops and establishing particular varieties of buffer crops to plant have the ability to mitigate crop damage by wildlife (Akankwasah, 2008; Akampulira et al., 2015).

Crop damage by wildlife management techniques such as guarding, lethal removal, and chasing wildlife that damage crops with help of domestic dogs complement buffer crops as mitigation to 
Vol. 06, No. 04; 2021

ISSN: $2456-8643$

mitigate crop damage by wildlife (Woodroffe et al., 2005; Hill, 2012), though they require a constant human presence. Most of these mentioned interventions require human presence, unlike the cultivation of buffer crops as mitigation to crop damage by wildlife.

Farmers bordering national parks such as Kibale plant several varieties of beans with bitter leaves which are not palatable to antelopes (Akampulira et al., 2015), though Akankwasah (2008) noted that planting buffer crops has the potential to reduce the diversity of food crops produced; there are no studies to prove that planting buffer crops could result in reduction in the diversity of food crops grown. Nevertheless, thisreview establishes non-staple crops that can be used as buffers depending on their level of deterring wildlife species that damage crops. However, current interventions and measures can complementplanting buffer crops. Some of these include physical barriers and guarding (Hill, 2012), making noise to chase away wildlife from gardens, lethal removal, and relocation of problem wildlife (Woodroffe et al, 2005).

Akampulira et al (2015), Sean (2016) analysed cultivation of tea and Mauritius thorns as buffer crops around Bwindi Impenetrable National Park and both studies reveal that tea and Mauritius thorns deterred gorillas and other primates respectively from damaging crop farms. The question still lingers as to why farmers around other protected areas are not adopting and planting such buffer crops to mitigate crop damage by wildlife. The finding on Mauritius thorns as a buffer to deter primates such as monkey is also supported by Mackenzie and Graham (2012) who discovered that the bio-fence deterred primates around Queen Elizabeth National Park. Farmers need to be sensitized on which buffer crops to grow to mitigate crop damage by wildlife around Kibale National Park.

Farmers are engaged in cultivation of high-value buffer crops such as Lemongrass and Artemisia (Nkuringo Buffer Zone - GMP, 2015-19). However, fewer studies, if at all none, have been conducted to determine how buffer crops mitigate crop damage by wildlife. Though it can be noted that cultivation of these buffer crops, creates employment, improves incomes, and enhanced livelihoods of farmers around BINP (Akampulira et al., 2015). Kalpers et al 2010 noted that the Mauritius thorn hedges around Nkuringo were effective in deterring primate raids since members of the community were involved in their maintenance.

Tea a high-value crop acts as a buffer when the tea bush has fully established, this has helped to control crop damage by wildlife and contribute to community livelihoods around Kibale National Park in Uganda (UWA, 2015). Tea proves as an effective buffer crop only when it is fully maintained, free of other indigenous plants and shrubs which can attract wildlife (Akampulira $e t$ $a l ., 2015)$. If not fully maintained buffer crops such as tea can harbour wildlife that eventually damages crops.

Crop damage by wildlife in absence of buffer crops was mentioned as the reason why farmers bordering National Parks preferred to grow trees though they harboured crop raiders (McGuiness, 2016). Tree growing reduced incidence rates of crop-raiding and provides an opportunity for farmers to plant commercial tree species such as eucalyptus. The growing of eucalyptus as short-term commercial tree species provided farmers an alternative source of 
Vol. 06, No. 04; 2021

ISSN: $2456-8643$

income through sales of commercial timber. Trees are rarely foraged upon by wildlife (Nyirenda et al., 2013).

The absence of buffer crops escalates elephant foraging around national parks in Uganda (Nampindo, 2005). Foraging by wildlife can escalate incidence rates of crop damage by wildlife that is counteracted in most cases by guarding (Hill, 2010). Crop damage by wildlife can result in increased school dropouts (Hill, 2017). Children do not attend school as they have guard crops against wildlife from damaging crops. Cultivationof pasture, Artemisia, lemongrass, and tea as buffer crops to reduce incidence rates of crop damage in Nkuringo (Kalpers et al., 2010) seemed to relieve children of the burden of missing out on schooling as they were no longer involved in guarding crop farms. Buffer crops cultivation mitigates human-wildlife conflicts (Hockings, 2009; Fulconis and Gross, 2011; Hill, 2020).

Loss of crops to wildlife is a potential source of human-wildlife conflict- HWC (Hockings, 2009), as farming close to the forest edge is a predictor of crop damage by wildlife (NaughtonTreves et al., 2011). Hill (2012) discovered that guarding crops during the day from wildlife crop-feeders proved effective, but required constant human presence. In absence of effective compensation schemes, farmers can exaggerate claims to crop damage by wildlife (Sitati et al, 2005). Effective buffer crops could provide a solution to wildlife crop-feeding and damage, a major source of HWC, and loss of agricultural livelihoods of farmers living near protected area boundaries. Tea as a buffer crop inhibits human encroachment on the park and crop damage by wildlife on smallholder crops (Brad and Jon, 2004).

Some $85 \%$ of crop damage events around KNP were associated with six species, namely baboons, elephants, red tail monkeys, bush pigs, and chimpanzees (Naughton-Treveset al.,2011). Maize and cassava were occasionally destroyed. Crop damage by wildlife is happening amid protected area management investing heavily in the digging of trenches, planting Mauritius thorns (West et al., 2006).In her study, Naughton-Treves (2008) notes that farmers on average lost $3.5 \%$ of banana fields by area, $6.8 \%$ of cassava fields, and $5.5 \%$ of maize fields. This poses a threat to agricultural livelihoods despite the existence of some deterrent methods such as guarding (Hill, 2012), trenches, planting Mauritius thorns (West et al., 2006). Crop damage by wildlife creates hostility and resentment among farmers (Lichtenfeld et al.,2014). Crop damage takes several forms (Muruthi, 2005) such as trampling, foraging, and whole plant ingestion by wildlife. Crop damage by wildlife could put household food security at risk (Davari, 2000). Around Queen Elizabeth Conservation Area (QECA), crop-raiding of maize and beans was an excuse given for poaching (CARE, 2005).

Gail et al., (2012) noted that some 73\% of incidents of crop damage by wildlife in Sumatra were on fruit crops. Farmers on average lost their jack fruits at 38\%, Jengkol at 15\%, 13\% rubber, 4\% durian, and 3\% petai. All these crops were lost to orangutans (arboreal ape native to Sumatra), as noted earlier by Naughton-Treves et al., (2011) Kibale National Park's (KNP) six of the 13 primates are crop feeders, thus the damage occasioned by primates could as well be six times for farmers living near KNP. As noted by Bloomfield et al., (2020) crop damage reduces support for conservation efforts. 
Subsistence farmers living near Gishwati Forest reported 10-20\% of household income lost to crop damage by wildlife by chimpanzees (Pan troglodytes Schweinfurthii) and vervet monkeys (Shane and David, 2014). The major food crops lost were maize (Zea mays), sweet potato (Ipomea batatas), and beans (Phaseolus vulgaris). In a study by Naughton-Treves et al., (2011), crop fields lying within $500 \mathrm{~m}$ of KNP, farmers on average completely lost 4-7\% of their cassava and maize crops. This trend shows stable crop loss, which implies agricultural livelihoods. These are some of the causes of resentment of wildlife by farmers as noted by Lichtenfeld et al., (2014).

Crop damage by wildlife sometimes is a single most important determinant of crop yields (Hill, 2017). According to the Optimal Foraging Theory (OFT) crop damage by wildlife is facilitated by forage availability within a protected area (Chiyo et al., 2005). The more, the forage is within a protected area, the lesser the chances of crop damage by wildlife. The tenets of OFT such as influence of seasonal changes which result in reduced forage for wildlife influence animal movements to search for quality forage outside protected areas. In absence of buffer crops and increasing forage unavailability in Kibale National Park, this triggers nutritional stress among wildlife hence crop damage. The availability of palatable crops on farmlands escalates crop damage by wildlife beyond protected area boundaries throughout the year (Rusokeet al., 2020). Cultivation of buffer crops gives insights to mitigation of crop damage by wildlife around Kibale National Park in Uganda.

Osborn and Parker (2003) note that the timing to crop damage is triggered by nutritional stress caused by a decline in quality and nutritive value of natural forage inside the protected area. Crop damage occurs throughout the year and it is triggered by nutritional stress (Mackenzie et al., 2018). Whereas crop damage occurs throughout the year with peak seasons experienced during the dry season (Mackenzie et al., 2018). It is, therefore, important for farmers to adopt buffer crops that are less nutritive to wildlife. Buffer crops such as tea grown around other national parks such as Bwindi Impenetrable National Park (Akampulira et al., 2015) were found to be effective against gorilla damage on crops.

Chiyo et al., (2005) attributed temporal crop-raiding behaviour of wildlife species to crop availability at certain phenological stages which in turn are driven by seasonal patterns in rainfall. Decisions on farmer's participation in mitigation of crop damage by wildlife through planting of buffer crops can be guided by how seasons of the year influence the types of crops grown as attractants to crop damage by wildlife (Hill, 2017). The Optimal Foraging Theory (OFT) is supported by the availability of forage within the protected area, the nutritive value of forage, the season of the year, and crops grown by farmers. These aspects elucidate the feeding strategies of wildlife species. Nishant et. al. (2019) observed that crop-raiding which results in crop damage maximizes nutrients for wildlife. This is so during periods of natural forage availability. If farmers adopt buffer crops that are less palatable to wildlife, crop damage by wildlife can be mitigated. 
Barry (2006) notes that chances are when observing animals in the wild, you are most likely to see them foraging for food. If successful, their foraging efforts culminate in feeding. Wild animals' searches, sense, detect, and feed. Therefore, wild animals do not intentionally feed to destroy crop farmlands, but because farmers grow crops that are of more nutritive value, this compounded by insufficient forage in the protected area due to carrying patterns of rainfall distribution (Fynn et al., 2015), wildlife species are attracted to invade farmlands and damage crops grown by farmers.

\section{Effect of crop damage by wildlife on crops grown in absence of buffer crops}

Crop damage by wildlife is a threat to agricultural livelihoods of farmers bordering protected areas such as Kibale National Park in absence of buffer crops (Hill, 2009). Eight five percent ( $85 \%)$ of crop damage by wildlife around Kibale National Park is caused by five wildlife species namely: Olive baboons (Papio anubis), wild pigs (Scrus scrofa), red-tailed monkeys (Cercopithecus ascanius), chimpanzees (Pan troglodytes), and elephants (Loxodonta africana) as studied by Naughton-Treves et al., (2011). Crop damage by wildlife as a potential source of human-wildlife conflict (Fulconis and Gross, 2011; Shaurabh and Sindhu, 2017) and cultivation of buffer crops as mitigation measure to wildlife damage on crops has not been extensively documented (Akampulira et al., 2015).

In absence of buffer crops cultivation, Mackenzie and Ahabyona (2011) observed that crop damage by wildlife led to financial losses of US\$74 (an equivalent of $1.5 \%$ median household capital asset wealth) and this damage was experienced within 5000m of Kibale National Park (KNP) forest boundary. Sudip and Siddhartha(2015) emphasize the identification and quantification of crop damage but quickly assert that the means used for crop protection and their effectiveness is limited.

Some staple crops grown by farmers suffer maximum or total damaged by wildlife (Rao et al., 2012). Monkeys and wildlife boars in Himalaya accounted for 50-60\% of crop damage, Around Kibale National Park, Olive baboons (Papio anubis), wild pigs (Sus scrofa), red-tail monkeys (Cercopithecus ascanius), chimpanzees (Pan troglodytes schweinfurthii), and elephants (Loxodonta africana) were responsible for the 85\% crop damage (MacKenzie and Hartter 2013). Food-grains and horticultural crops such as apples suffered maximum damage (Rao et al., 2012). Gardens of potatoes suffered $43.6 \%$ of crop damage by wildlife, the projected loss in crop yields by 2002 in four villages found within Garhwal Himalaya wildlife reserve accounted for USD 15389. In a study conducted by Hill (2010), $70 \%$ of farmers around the Budongo Forest in Uganda associated crop losses to baboons and bush pigs (Hill, 2017). Trends in crop damage by wildlife show an increase in damage with increasing distance to protected area boundaries.

Crop damage by wildlife creates a competitive nutritional intake between humans and nonhuman primates (Feuntes et al., 2005). Crop damage by wildlife is a global concern (Hill, 2010; Naughton-Treves et al, 2011; Saj et al., 2011). Crop damage happens at different crop growth and development lifecycles [crop phenology - Onojeghuoet al., 2018]. Since crops are damage at different stages of growth, crop damage by wildlife management is a complex issue.NaughtonTreves et al., (2011) noted that crop damage by wildlife was associated with residing and 
cultivation of crops closer to the forest edge. Farmers around Budongo forest lost maize to baboons and cassava to bush pigs. Guarding of crop farms (Hill, 2012) against bush pigs was presumed dangerous as some farmers lost their lives through attacks from wounded bush pigs. Cultivation of buffer crops offers a remedy to crop damage by wildlife as the technique does not require a human presence.

Crop damage by wild animals is further seen as a potential source of conflict between humans, animals, and protected area management as farmers lose agricultural livelihoods to wildlife crop feeders (Kaggwa et al 2009; Lee, 2005; Linkie et al., 2007). For instance, Kaggwa et al., (2009) observed that wildlife continues to destroy crops, a major cause that results in agricultural losses for farmers neighbouring protected areas. Also, Linkie 2007 notes that where farmers are unable to mitigate animal-crop damage adequately and in absence of effective compensation schemes, the retaliatory killing of wildlife is common. Effectively, there is a need to effective buffer crops farmers can plant to mitigate crop damage by wildlife.

\section{Effect of crop farmers involvement in planting of buffer crops as a mitigation measure to crop damage by wildlife}

Whereas conservation objectives aim to protect wildlife and their habitats, farmer's objectives and aspirations are geared towards the expansion of crop production (Lewis, 2007). Sometimes farmer's aspiration aims to maximize agricultural output by encroaching on wildlife habitats (Nyirenda et al., 2011). To maximize agricultural output, farmers can be involved in cultivation of buffer crops. Such efforts could mitigate crop damage by wildlife.

Rao et al (2012), suggests that farmers can be encouraged to grow medicinal plants. These changes cropping and crop composition. Medicinal plants are crops of high economic value, but low volume crops in terms of nutritive value. As earlier noted by Chiyo et al (2005), wildlife species mainly select crops of high nutritive value, low nutrient crops such as those with medicinal properties might mitigate crop damage by wildlife.

Studies by Terborgh et al., (2002); Gureja et al., (2002); Sethi (2003); Woodroffe et al., (2005); West et al., (2006); Ogra and Badola, (2008) agree to some extent that damage to crops by wildlife is a natural phenomenon that presumably existed since the origin of agriculture. King et al., (2017) observed that crop damage by wildlife is on the rise and it can no longer be tolerated by farmers. Kibale National Park has a high density of primates, measures to protect crops from damage by wildlife are met with limited success (Watve et al., 2015). Involving farmers in mitigation of crop damage by wildlife through cultivation of buffer crops contribute to the already existing measures, methods, and techniques to deal with crop damage by wildlife such as guarding with help of dogs (Hill, 2012).

Crop damage by wildlife significantly remains a challenge to conservationists and leads to loss of agricultural livelihoods close to $90 \%$ (Naughton-Treves et al., 2011). Akampulira et al., (2015) established that tea as a buffer crop was an effective intervention against gorilla crop damage around Bwindi Impenetrable National Park, thus there is a need to establish several types of buffer crops that can be planted by farmers against wildlife species that damage crops around Kibale National Park. 
Crop damage by wildlife affects people's livelihoods (Krithi et al., 2017). A study conducted by Tweheyo et al., (2012) shows that farmers continue to employ several control measures to mitigate crop damage by wildlife. Methods such as guarding, poisoning, killing, and fencing around Lake Mburo are so tedious and time-consuming. The findings from Tweheyo et al., (2012) study show the types of crops grown may influence attraction to wildlife. Destruction of crops such as beans (Phaseolus vulgaris) was reported at 83\% (Tweheyo, et al., 2012). The damage was caused by bushbucks (Tragelaphus imberbis). Involving farmers in mitigation of crop damage by wildlife to enhance income and food security is imperative (Fig.1).

Concept of Buffer Crop cultivation as mitigation measure against crop damage by wildlife Independent Variable

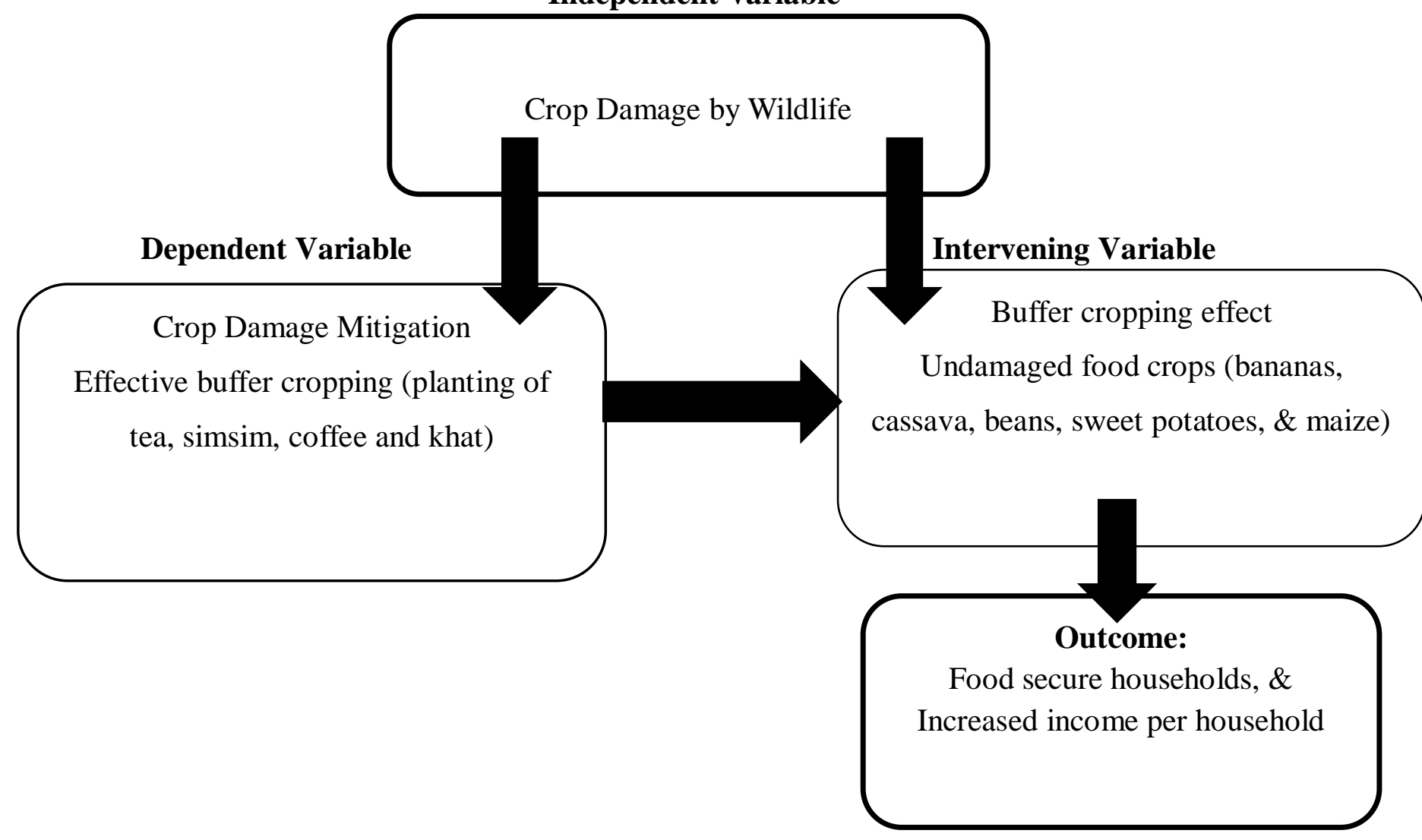

Figure 1: Conceptual model of variables.

\section{DISCUSSION}

Damage to crops by wildlife species is an important but underestimated problem, farming near the protected exposes farmers to loss of agricultural livelihoods from crop damaging wildlife (Watve et al., 2015). Wildlife damage to agriculture causes significant economic losses globally and threaten food security (Imre et al., 2020). Evaluating the effect of buffer crops as a mitigation measure to crop damage by wildlife amongst farmers around KNP is expected to 
Vol. 06, No. 04; 2021

ISSN: $2456-8643$

reduce agricultural losses. Farmers living close to protected areas are bound to suffer individual crop loss and damage from wildlife (Naughton-Treves et al., 2011). As animals move from their natural habitat to feed on farmer's crops in agricultural fields can be interpreted as crop damage by wildlife (Sillero-Zubiri and Switzer, 2001).

A total of $79.83 \%$ of farmers cultivation crops close to protected areas boundaries associate opportunity costs of crop damage by wildlife with loss of sleep and cost of time for other chores, when providing crop protection (Nyirenda et al., 2013). Actual crop losses for mono-specific stands of maize and cotton were reported at $7.7 \%$ when animals cause damage to crops (Osborn and Parker, 2003). Crop damage by wildlife can be of several forms such as trampling, browsing, gnawing, or rubbing (Aparna, 2015). From literature survey, no study has been conducted around Kibale National park regarding planting of buffer crops as crop damage by wildlife mitigation measure. Studies by Akampulira et al., (2015), and Bitariho et al., (2019) on effectiveness of problem animal management strategies are mainly concentrated around Bwindi Impenetrable National Park in south-western Uganda. This is a major research gap that the review on buffer crops as mitigation measure to crop damage by wildlife around Kibale National Park addresses.

Crop damage by wildlife can expose households to food insecurity as major food crops are lost to wildlife; this can result in shortages of nutritional supplements and inadequate food reserves (Hill, 2017). As noted by Chapman and Lambert (2000), of the 13 primates found in Kibale National Park (KNP), 6 are recorded to cause crop damage. Half of the primates being recorded as crop-feeders continue to threaten farmer's agricultural livelihoods around KNP. Deterrents such as beehive fences (King et al, 2011) have proved more effective as compared to Mauritius thorn fences. This review on buffer crops as a mitigation measure to crop damage by wildlife adds knowledge to the existing interventions and deterrents through the establishing effective buffer crops such as khat which is cultivated by farmers in Kabarole district around Kibale National Park in Uganda.

Crop damage by wildlife which is a function of distance from the protected area, types of crops grown, type of crop-raiding species, the season of the year, and population density results in loss of agricultural livelihoods, destruction of farm structures and retaliatory killings (Sitati et al., 2005). Crop damage by wildlife can be solved through cultivation some buffer crops such as tea (Akampulira et al., 2015). Identification of buffer crops, based on knowledge of crop grown by farmers, understanding farm location from the protected area, and appropriate crop growth seasons, buffer crops could prove effective in mitigation of crop damage by wildlife around Kibale National Park.

The conceptual framework in Figure 1.1 shows the relationship between crop damage by wildlife (independent variable) which leads to loss of farmers livelihoods in terms of yields. Crop damage by wildlife can be mitigated through improving knowledge of farmers on which buffer crops to grow (intervening variable). Buffer cropping eventually leads to securing farmers livelihoods by mitigating loss in yields of the major food crops grown. Improving livelihoods of farmers requires them to grow effective buffer crops which have been reviewed. 
Vol. 06, No. 04; 2021

ISSN: $2456-8643$

Buffer crops are regarded as crops which are not palatable to wildlife, yet of agricultural value to farmers. The choice and type of buffer crops are dependent on farmer's knowledge and sensitization about the values of such crops. Some buffer crops are also known to be traditional crops grown among communities. Akampulira et al., (2015) noted tea on a pilot study was found to be an effective buffer crop against gorillas in Bwindi Impenetrable National Park. This review on buffer crops as a mitigation measure against crop damage by wildlife explores which buffer crops are grown to mitigate the loss of yields to wildlife around Kibale National Park.

Crop foraging by wildlife aims at obtaining food which in turn provides the animal with energy, searching for and capturing the food requires both energy and time (DiRienzo et al., 2012) as explained by Optimal Foraging Theory (OFT). OFT further stipulates that an animal's decision to feed is made to maximize net energy gain according to diet choice, location, and time (Stephens and Krebs 1986). These tenets influence crop damage by wildlife around protected areas, making OFT an appropriate theory to underpin the review on buffer crops as a mitigation measure to crop damage by wildlife. Foraging species encounter several food types randomly, which are ranked according to their energy content relative to time spent foraging (Shipley et al., 2009). Wildlife species food consumption patterns relate to seasonality, habitat quality, food abundance, and distribution (Chiyo et al., 2005; Jamam and Huffman, 2008). As noted by Chiyo et al (2005), high nutritive value is found in planted crops than wild plants. Optimal Foraging Theory explains crop damage by wildlife. If farmers plant less palatable crops also known as buffer crops, chances are these crops shall be selected for foraging by wildlife. In most habitats, food quality and abundance vary seasonally because plant growth and phenology are induced by rainfall distribution patterns (DieRienzo et al., 2012).

The optimal foraging theory (OFT) explains why crop-raiding and damage have persisted around protected areas. Osborn and Park (2003) assert that crop foraging by elephants are triggered by nutritional stress caused by a decline in the quality and nutritive value of natural forage. Thus, cultivated crops are a major attractant influencing foraging patterns that result in crop damage. Crop raiding and damage maximize nutrient intake during periods of scarcity in natural forage (Sukumar, 1991). Cultivated crops are known to be richer in macronutrients and mineral salts, than wild plants of the same taxa (Mackenzie et al., 2017). In absence of buffer crop cultivation and effective compensation schemes, there is increasing crop damage by wildlife which leads to resentment of wildlife.

A theoretical model of community-operated compensation scheme was developed by Watve (2015) with compensation based on the net loss in production, rather than a visual estimate of damage. Under the community operated compensation scheme, the average loss in net produce is estimated over a belt with the comparable risk of damage. The compensation payable is calculated based on the average loss but is paid in proportion to individual farm's produce. Analysis based on principles of behavioral economics shows that this compensation scheme would facilitate good agricultural inputs and honesty in reporting produce lost to wildlife cropfeeders. The scheme also effectively segregates wildlife damage from other forms of agricultural loss. However, compensation schemes for crop damage are expensive ventures and can be 
Vol. 06, No. 04; 2021

ISSN: $2456-8643$

marred by corruption (Ogra and Badola, 2008). Planting buffer crops can mitigate crop damage by wildlife.

According to Naughton-Treves et al., (2011), Africa's wildlife has fared poorly in the $20^{\text {th }}$, colonial wildlife ownership emphasized the creation of parks and restrictions on hunting technology, though Toro royals enjoyed privileged access to the big game. Wildlife kept in National Parks, where it was later decimated by war and poaching, however, today recovering wildlife populations destroy crops when they stray into densely settled agricultural farms. Cultivation tea as a physical buffer crop (Brad and Jon, 2004) unintentionally promotes conservation of Kibale forest; crop damage by wildlife still causes agricultural livelihoods loss (Woodroffe et al., 2005). Buffer crops such as the gauging of tea as buffer crops around Bwindi Impenetrable National Park (Sean, 2016), could provide insights on the identification of effective buffer crops farmers can grow to mitigate the agricultural loss to crop damage by wildlife.

In Tooro Kingdom, where Kibale National Park (KNP) is located (Businge et al., 2019), wildlife management centered on spiritual appeasement and hunting rights, this had decimated wildlife populations (Hill, 2017). Crop damage by wildlife is a major problem around KNP which creates resentment, sometimes elephants are killed en-masse (Bortolamiol et al., 2018). During the mid$19^{\text {th }}$ century when the Government of Uganda started the creation of National Parks, the recovering wildlife populations started to stray into densely cultivated agricultural lands causing crop damage (Naughton-Treves et al., 2011). Recovering animal populations around KNP, translate to increased crop damage by wildlife (Mackenzie et al., 2015) since most species in a class of primate genera include crops in their diet (Hill, 2017).

Farmers around Kibale National Park are primarily subsistence agriculturalists with minimal livestock holdings. Household losses accrued due to living next to KNP have been primarily caused by crop-raiding (MacKenzie 2012), with elephants and olive baboons (Papio anubis) causing $93.5 \%$ of crop damage by area (MacKenzie and Ahabyona 2012). Village population densities were $70-611$ people $\mathrm{km}^{2}$ with $42-241$ households per village (MacKenzie and Hartter, 2013).

In her book (chasing baboons or attending class: protected areas and childhood education in Uganda), Mackenzie et al., (2015), discovered that households living within $3.5 \mathrm{~km}$ of KNP have to guard their food crops against park-protected wildlife. Children and their parents guarded against elephants at night and primates during the day. So, when do they go to school? Most children do not complete primary school. So how can they go to secondary school or university?' (Mackenzie et al., 2015). Forty-one percent of the enrolled children came from households that permitted their children to guard crops against one to seven days per week during high wildlifedamaging seasons (May-July, and November-January); 'We hold children back from school to guard against crop damage by wildlife. If crop damage could be stopped, then our children could go to school' (Mackenzie et al., 2015), such children are likely to turn into poachers later in life. These children move around crop gardens sounding empty tins, making alarms, throwing stones from morning to dusk to scare away wildlife-crop feeders, there is a need to address the damage of crops by wildlife. In some cases, dogs are used to chase away some wildlife crop-feeders. All 
Vol. 06, No. 04; 2021

ISSN: $2456-8643$

these are common sights during the crop fruiting and harvesting seasons around KNP. To remedy the plight of farmers, there is a need to evaluate how buffer crops can mitigate crop damage by wildlife.

About $80 \%$ of Ugandans rely on agriculture; most of these are farmers found in the countryside and some are neighbours to protected areas. These farmers continue to suffer agricultural losses as a result of crop damage by wildlife (Jason and Eric, 2009). Unfortunately, almost the deterrent techniques such as 'planting' scarecrow in crop gardens to scare away wildlife species are laborious, time-consuming, and guarding require constant human presence (Hill, 2012). The need to evaluate buffer crops as a mitigation strategy to crop damage by wildlife is imperative to ensure sustained agricultural livelihoods and avoid related consequences such as food insecurity and retaliatory killing of wildlife species (Linkie et al., 2007).

In examining buffer crops as mitigation measure to crop damage by wildlife, comprehensive information on crop damage by wildlife species is critical. Therefore, effective strategies for controlling crop damage by wildlife must be formulated (Rematosa et al., 2008). Determining the effect of crop damage by wildlife on yields of major food crops grown in the absence of buffer crops gave insights into solutions by farmers that were aimed to reduce crop damage by wildlife.

The review on buffer crops as mitigation measure to crop damage by wildlife established the types of buffer crops grown by farmers to mitigate crop damage around Kibale National Park. Buffer crops can be described as plants which are either less-palatable or non-palatable to wildlife (Hoare, 2012). It is believed that these crops create a low-conflict barrier, enrich the forest edge of a protected area, and entice wildlife species to remain in the forest or Protected Area (PA). Buffer crops are beneficial to farmers (Senthilkumar et al., 2016). Supplying farmers with buffer crop planting materials have been recommended to mitigate crop damage by wildlife around Kibale National Park. Through this contribution, the study revolves on some of the issues related to crop damage by wildlife such as time spent guarding crops; safeguard agricultural livelihoods and mitigate crop damage by wildlife that occurs at night when farmers retire to sleep (Barnes et al., 2007). This review of buffer crops as mitigation measure to crop damage by wildlife indirectly increases school enrolment as children will no longer have to keep guarding gardens from crop damaging wildlife, and also help to reduce compensation fees spent by the Uganda Wildlife Authority in compensating farmers who have lost their crop to wildlife as proposed in the Uganda Wildlife Act of 2019.

At the policy level, the Uganda Wildlife Act 2019, provides for a list of species where farmers can be compensated when their crops are damaged. The four major wildlife species such as redtailed monkey (Cercopithecus ascanius), vervet monkey (Cercopithecus aethiops), black and white colobus (Colobus guereza), L'Hoest's monkey (Cercopithecus lhoesti), are not listed (Uganda Wildlife Act, 2019). This creates a policy gap that can be bridged by farmers adopting and planting buffer crops which are effective against damage by wildlife. Such buffer crops include tea (Camellia sinensis), coffee (Coffea spp) and khat (Catha edulis). Most methods for crop damage mitigation such as guarding, chasing wildlife from crop gardens, require constant 
human presence (Hill, 2017). Cultivation of buffer crops does not require constant human presence. Based on the review, the study has developed a conceptual model which indicates ways that can enable and encourage farmers to adopt and plant buffer crops as a mitigation measure to crop damage by wildlife (Figure 1).

\section{CONCLUSION AND RECOMMENDATIONS}

Farmers around Kibale National Park grow tea as the main buffer crop against elephants. In absence of buffer crops farmers lose crops to wildlife. Where farmers cannot effectively mitigate crop damage, retaliatory killings are reported. There are several other interventions for crop damage mitigation by wildlife such as guarding, digging elephant trenches and chasing wildlife from crop gardens. Most of interventions for crop damage mitigation require constant farmers presence. Increasing farmers participation in cultivation of buffer crops through sensitization is paramount to mitigation of crop damage by wildlife around Kibale National Park.

\section{Acknowledgement}

The authors of this review paper acknowledge Nkumba University for permitting them to use the internet and library resources while doing literature review at the University. The corresponding author (R.T), wishes to express his sincere appreciation to the co-author (O.F) who not only participated in conceptualization of the study but also offered guidance during the review process.

\section{Conflict of Interest}

The authors declare no conflict of interest.

\section{REFERENCES}

Akampulira E, Bitariho R, and Mugerwa B (2015). An assessment of the effectiveness of Nkuringo Buffer Zone in Mitigating Crop Raiding Incidences around Bwindi Impenetrable National Park, S.W. Uganda. A technical report for the International Gorilla Conservation Programme. PP 38.

Akankwasah B (2008). The effect of crop-raiding on household food security in the Albertine Rift: A case study of Queen Elizabeth National Park, western Uganda. Kampala, Uganda: Ministry of Tourism, Wildlife Antiquities, Kampala. PP 24.

Aparna CB (2015). Crop damage by mammals in some villages of Washim District, Maharashtra. Journal of Global Biosciences, 4:1954-1960.

Barnes RFW, Dubiure UF, Danquah E, Boafa Y, Nandjui AEM, Manford M (2007). Cropraiding elephants and the moon. African Journal of Ecology, 45:112-115.

Barry S (2006). Optimal Foraging Theory: Constraints and Cognitive Processes. Journal of Behavioural Ecology 3:325-330. 
Bitariho R, Akampulira E \& Twinomuhangi (2019). The effectiveness of problem animal mitigation interventions around Karangara and Bujwenge parishes, Kanungu District, Bwindi Impenetrable National Park, SW Uganda. Bwindi Mgahinga Conservation Trust. Uganda Wildlife Authority.

Bloomfield LSP, Tyler LM and Lambin LF (2020). Habitat fragmentation, livelihood behaviors, and contact between people and non-human primates in Africa. Landscape Ecology 35(4), 985-1000.

Bortolamiol S, Sabrina K, Collin AC, Kagoro W, Seguya A, Marianee C (2018). Wildlife and Spiritual Knowledge at the edge of protected areas: raising another voice in conservation. Ethnobiology and Conservation 7:12-16.

Brad GM, Jon DU (2004). The role of off-farm employment in tropical forest conservation: labour, migration, and smallholder attitudes toward land in western Uganda. Journal of Environmental Management 71:193-205.

Businge P, Rusoke T, Guma KA, Mpanga J, Bitamazire A, and Mbabazi GM (2019). The Great Kingdom of Tooro: Discover its Friendly People, Amazing Culture, and Hidden Treasures. Greatness University Publishers. ISBN: 978-1-913164-92-8. Vol. 1. p119.

CARE (2005).Reducing the costs of conservation to frontline communities in south-western Uganda. Knowledge Base Review Report. CARE International in Uganda, Institute of Tropical Forest Conservation, Conservation Development Centre, and Wildlife Conservation Society. P.130

Chapman CA, Lambert JE (2000). "Habitat alteration and the conservation of African primates: A case study of Kibale National Park, Uganda". American Journal of Primatology. 50 (3):169-185.

Chiyo IP, Cochrane EP, Naughton-Treves L, Basuta GI (2005). Temporal patterns of cropraiding by elephants: a response to changes in forage quality or crop availability? African Journal of Ecology. 43:48-55.

Davari MR (2000). Managing the population of offending animals by introducing a compensation scheme, Australian Centre for International Agricultural Research22: 299-301.

DiRienzo N, John RK, Stuart AW (2012).An introduction to Behavioral Ecology. West Sussex, UK: Wiley Blackwell. pp. 193-202. ISBN 978-1-4051-1416-5.

Fulconis R, Gross EM (2011). Annual Report 2010/2011. Awely, Wildlife, and People, Orleans, France.

Fynn RWS, David JA, Michael JSP, Michel de Garine-Wichatitsky (2015). Strategic management of livestock to improve biodiversity conservation in African savannahs: a 
Vol. 06, No. 04; 2021

ISSN: $2456-8643$

conceptual basis for wildlife-livestock coexistence. Journal of Applied Ecology: DOI:10.1111/1365-2664.12591

Gail C, Rabin S, Mathew L (2012). Evaluating the effectiveness of human-orangutan conflict mitigation strategies in Sumatra. Journal of Applied Ecology, 49:367-375. British Ecological Society.

Gureja N, Menon V, Sarkar P, Kyarong S (2002). Ganesh to bin Laden: human-elephant conflict in Sonitpur district of Assam. Wildlife Trust of India (New Delhi). Occasional Report No. 6.

Hill CM (2009). Primate Crop-raiding:A Study of Local Perceptions in Four Villages in North Sumatra, Indonesia. Primate Conservation 24:107-116.

Hill CM (2010). Crop-raiding by wild vertebrates: the farmers' perspective in an agricultural community in western Uganda. International Journal of Pest Management 43:77-84.

Hill CM (2012). Conflicting attitudes towards elephants around Budongo Central Forest Reserve, Uganda. Environ. Conserv. 25(3): 244-250.

Hill CM (2017). Primate Crop Feeding Behaviour, Crop Protection, and Conservation: International Journal of Primatology 38:385-400.

Hill CM (2020). Crop raiders in an ecological trap: optimal foraging individual-based modelling quantifies the effect of alternate crops. Ecological Applications, 10.1002/eap.2111

Hoare RE (2012). Lessons from 15 years of human conflict mitigation: management considerations involving biological, physical, and governance issues in Africa. Pachyderm 51:60-74.

Hockings KJ, Humle T (2009). Best practice guidelines for the prevention and mitigation of conflict between humans and great apes. Gland, Switzerland: IUCN/SSC Primate Specialist Group.

Hockings KJ (2009). Living at the interface. Social Animal Cognition 23:183-205. John Benjamin Publishing Company.

Imre K, Balint T, Gergely S, Sandor C, Bleier N (2020). The assessment of wildlife damage estimation methods in maize with simulation in a GIS environment. Crop Protection 127: 104171.

Jaman MF, Huffman MA (2008). Enclosure environment affects the activity budgets of captive Japanese macaques Macaca fuscata. American Journal of Primatology 70: 1133-1144. 
Kaggwa R, Hogan R, Hall (2009). Enhancing Wildlife's Contribution to Growth, Employment, and Prosperity: UNDP/NEMA/UNEP Poverty-Environment Initiative, Kampala-Uganda. Pg.22.

Kalpers J, Gray M, Asuma S, Rutagarama E, Makambo W, Rurangwa E (2010). Buffer zone management and Human-Wildlife Conflict Management. IGCP Lessons Learned.

King EL, Douglas-Hamilton I, Vollrath F (2011). Beehive fences as effective deterrents for crop-raiding elephants: field trials in northern Kenya. African Journal of Ecology 49:431-439. Blackwell Publishing Limited.

King LE, Fredrick L, Hesron N, Emmanuel M, Iain D (2017). Beehive fences as a multidimensional conflict-mitigation tool for farmers coexisting with elephants, Conservation Biology, 31, 4, (743-752).

Krithi KK, Arjun MG, De Fries R, Natasha B (2012). Assessing patterns of human-wildlife conflicts and compensation around a central Indian protected area. PloS one 7 (12).

Krithi KK, Shivangi J, Erika W (2017). Human-wildlife interactions and attitudes towards wildlife and wildlife reserves in Rajasthan, India. ORYX.

L'Roe $\mathbf{J}$ and Naughton-Treves $\mathbf{L}$ (2017). Forest edges in western Uganda: from refuge for the poor to zone of investment. Forest Policy and Economic 84, 102-111.

Lee PC (2005). Human attitudes to primates: perceptions of pests, conflict, and consequences for primate conservation. In: Paterson JD, Wallis J (eds.) Commensalism and conflict: the humanprimate interface. American Society of Primatologists, Norman, p 1-23.

Lewis DM (2007). Opportunities and constraints for protected area management through increased connectivity to local livelihood need in surrounding border areas: lesions from Luangwa Valley, Zambia In Redford KH, and Fearn E (eds.). Protected areas and human livelihoods. Working Paper No. 32. Wildlife Conservation Society New York, pp.38-49.

Lichtenfeld LL, Trout C, Kisimir EL (2014). Evidence-based conservation: predator-proof bomas protect livestock and lions. Biodivers Conserv 24:483-491. https://doi.org/10.1007/s10531-014-0828-x

Linkie M, Dinata Y, Nofrianto A, Leader-Williams N (2007). Patterns and perceptions of wildlife crop raiding in and around Kerinci Seblat National Park, Sumatra. Animal Conservation, 10(1), 127-135.

MacKenzie CA (2012). Accruing benefit or loss from a protected area: location matters. Ecological Economics 76: 119-129.

Mackenzie CA and Ahabyona P (2011). Elephants in the garden: Financial and social costs of crop-raiding. Ecological Economics 75:72-82. 
Vol. 06, No. 04; 2021

ISSN: $2456-8643$

MacKenzie CA and Graham EW (2012). Crop protection and conflict mitigation: reducing the costs of living alongside non-human primates. Biodiversity and Conservation 21:2569-2587.

MacKenzie CA and Hartter J (2013). Demand and proximity: drivers of illegal forest resource extraction. Oryx 47: 288-297.

Mackenzie CA, Raja R, Ridhwana K (2015). Chasing baboons or attending class: protected areas and childhood education in Uganda. Environmental Conservation 42: 373-383. Cambridge University Press.

Mackenzie CA, Salerno J, Hartter J, Chapman CA, Reyna R, Mwesigye TD, Drake M (2017). Changing perceptions of protected area benefits and problems around Kibale National Park, Uganda. Journal of Environmental Management 200:217-228

MacKenzie FJ, Krithi KK, \& Erika W (2018). Compensation as a Policy for Mitigating Human-wildlife Conflict Around Four Protected Areas in Rajasthan, India. Conservation and Society 16:305-319.

McGuiness SK (2016). Perceptions of crop-raiding: effects of land tenure and agro-industry on human-wildlife conflict. Animal Conservation 19: 578-587.

McLennan MR, Hill CM (2012). Troublesome neighbors: Changing attitudes towards chimpanzees (Pan troglodytes) in a human-dominated landscape in Uganda. Journal for Nature Conservation: 20:219-227.

Muruthi P (2005). Human-wildlife Conflict: Lessons learned from African Wildlife Foundation's heartlands. AWF, Nairobi.

Nampindo S (2005). The role of elephants (Loxodonta africana) in forest-savanna vegetation in Rabongo forest, Kampala, Uganda, Makerere University, Faculty of Forestry and Nature Conservation, p.93.

Nath NK, Dutta SK, Das JP, Lahkar BP (2015). Quantification of damage and assessment of economic loss due to crop raiding by Asian elephant (Elephas maximus): A case study of Manas National Park, Assam, India. J. Threatened Taxa, 7(2): 6853-6863.

Naughton-Treves L, Alix-Garcia J \& Chapman CA (2011). Lessons about parks and poverty from a decade of forest loss and economic growth around Kibale National Park, Uganda. Proceedings of the National Academy of Sciences 108(34): 13919-24.

Nishant S, Vinod K, Srinivas V, Raman S, Anindya S (2019). All-Male Groups in Asian Elephants: A Novel, Adaptive Social Strategy in Increasingly Anthropogenic Landscapes of Southern India, Scientific Reports, 10.1038/s41598-019-45130-1, 9, 1, (2019). 
Nkuringo Buffer Zone - GMP, 2015-2019. Nkuringo General Management Plan. BwindiMgahinga Management Trust, Kisoro Uganda.

Nyirenda VR, Chansa WC, Myburgh WJ, Reilly BK (2011). Wildlife crop depredation in the Luangwa Valley, eastern Zambia. J. Ecol. Nat.Environ. 3(15):481-491.

Nyirenda VR, Willem JM, Brian KR, Andrew IP, Harry NC (2013). Wildlife-crop damage valuation and conservation: conflicting perception by local farmers in Luangwa Valley, eastern Zambia. International Journal of Biodiversity Conservation, 5:741-750.

Ogra M, Badola $\mathbf{R}$ (2008). Compensating human-wildlife conflict in protected area communities: ground-level perspectives from Uttarakhand India. Hum. Ecol., 36:771-729.

Onojeghuo OA, George AB, Qingming W, Peter MA, Daniel K, Yuxin M (2018). Rice crop phenology mapping at high spatial and temporal resolution using downscaled MODIS timeseries, GI Science and Remote Sensing, 55:5, 659-677, DOI: 10.1080/15481603.2018.1423725.

Osborn FV, Parker GE (2003). Linking two elephant refuges with a corridor in the communal lands of Zimbabwe. African Journal of Ecology 41, 68-74.

Rao KS, Maikhuri RK, Nautiyal S, Saxena KG (2012). Crop damage and livestock depredation by wildlife: a case study from Nanda Devi Biosphere Reserve, India. Journal of Environmental Management 66:317-327.

Rematosa P, Mónica I, Lee A, Humberg, James CB, Olin ER (2008). Modeling wildlife damage to crops in northern Indiana. Human-Wildlife Conflicts, 2:225-239.

Rusoke T, Mbahinzireki G, Orach-Meza FL (2020). Philosophical perspectives on wildlife crop damage and management. Dir. Res. J. Agric. and Food Sci. 8. p.177-184. ISSN 2354-4147: DOI 10.26765/DRJAFS596018732. https://directresearchpublisher.org/drjafs/abstract/philosophical-perspectives-on-wildlife-cropdamage-and-management.

Saj TL, Sicotte P, Paterson JD (2011). The conflict between vervet monkeys and farmers at the forest edge in Entebbe, Uganda. - African Journal of Ecology 39: 195-199.

Sean M (2016).Study gauges use of tea as a buffer crop to curb mountain gorilla raids. Journal of Animal Conservation 26:1-23.

Senthilkumar K, Mathialagan C, Manivannan MG, Jayathangaraj G, Gomathinayagam M (2016). A study on the tolerance level of farmers toward the human-wildlife conflict in the forest buffer zones of Tamil Nadu: Veterinary World, 9(7): 747-752. 
Sethi N (2003). Battle Zone: Afterward, an eerie silence. Down to Earth, March issue (web document). http://www.downtoearth.org.in/default20030331.html

Shane MG, David T (2014). Farmers' Perceptions and Actions to Decrease Crop Raiding by Forest-Dwelling Primates around a Rwandan Forest Fragment. Human Dimensions of Wildlife, An International Journal; 19: 179-190. Taylor and Francis Online.

Shaurabh A, Sindhu R (2017). Investigating trends in human-wildlife conflict: is conflict escalation real or imagined? Journal of Asia-Pacific Biodiversity, 10, 2, (154).

Shipley LA, Forbey JS, Moore BD (2009). Revisiting the dietary niche: When is a herbivore a specialist? Integrative and Comparative Biology. 49 (3): 274

Seiler N, Robbins MM (2015). Factors Influencing on Community Land and Crop Raiding by Mountain Gorillas. Animal Conservation 24:1-8.

Sillero-Zubiri C, Switzer D (2001).Crop raiding primates: searching for an alternative, humane ways to resolve conflict with farmers in Africa. People and Wildlife Initiative. Wildlife Conservation Research Unit, Oxford University, Oxford, UK.

Sitati NW, Walpole MJ, Leader-Williams N (2005). Factors affecting susceptibility of farms to crop raiding by African elephants: using a predictive model to mitigate conflict. Journal of Applied Ecology, 42(6), 1175-1182.

Stephens DW, Krebs JR (1986). Optimal Foraging Theory. Princeton: Princeton University Press.

Sudip P and Siddhartha BB (2015). Crop protection and Its Effectiveness against Wildlife: A case study of Two Villages of Shivpuri National Park, Nepal. Nepal Journal of Science and Technology 16:1-10.

Sukumar RG (1991). The management of large mammals about male strategies and conflict with people. Biological Conservation, 55: 93-102.

Tania LS, Pascale S, Paterson JD (2001). The conflict between vervet monkeys and farmers at the forest edge in Entebbe, Uganda. African Journal of Ecology. 39:195-199.

Terborgh JC, Van SL, Davenport M, Rao (Eds) (2002). Making Parks Work: Strategies for Preserving Tropical Nature, Island, Washington, DC.

Tweheyo M, Mwesigye DT, Turyahabwe N, Asiimwe A, Orikiriza L (2012). Wildlife damage and control methods around Lake Mburo National Park, Uganda. International Journal of Pest Management, 58:25-31. 
Uganda Wildlife Act (2019). Ministry of Tourism, Wildlife and Antiquities, Kampala Uganda.

Uganda Wildlife Authority (2015). Kibale National Park: Management Plan 2015-2024. Uganda Wildlife Authority, Kampala, Uganda.

Watve MP, Patel KB, Abhijeet PP (2015). A theoretical model of a community-operated compensation scheme for crop damage by wild herbivores. Global Ecology and Conservation, 5:58-70.

West P, Igoe J, Brockington D (2006).Parks and people: The social impact of protected areas. Annu. Rev. Anthropol., 35:251-277

Woodroffe R, Thirgood S, Rabinowitz A (2005). The future of coexistence: Resolving humanwildlife conflict in a changing world. In R. Woodroffe, S. Thirgood, \& A. Rabinowitz (Eds.), People and wildlife: Conflict or coexistence. Cambridge, UK: Cambridge University Press, London. 